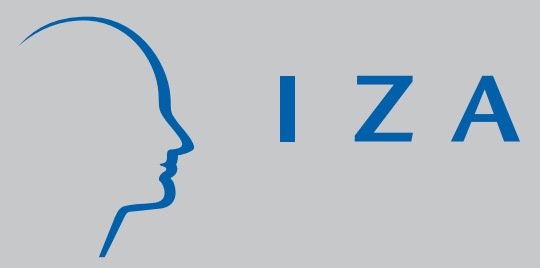

IZA DP No. 2

East-West Trade and Migration:

The Austro-German Case

Rudolf Winter-Ebmer

Klaus F. Zimmermann

April 1998 


\title{
EAST-WEST TRADE AND MIGRATION: THE AUSTRO-GERMAN CASE
}

\author{
Rudolf Winter-Ebmer \\ Klaus F. Zimmermann
}

\author{
Discussion Paper No. 2 \\ April 1998
}

IZA

P.O. Box 7240

D-53072 Bonn

Germany

Tel: +49-228-3894-201

Fax: +49-228-3894-210

Email: iza@iza.org

This Discussion Paper is issued within the framework of IZA's research area Internationalization of Labor Markets and European Integration. Any opinions expressed here are those of the author(s) and not those of the institute. Research disseminated by IZA may include views on policy, but the institute itself takes no institutional policy positions.

The Institute for the Study of Labor (IZA) in Bonn is a local and virtual international research center and a place of communication between science, politics and business. IZA is an independent, nonprofit limited liability company (Gesellschaft mit beschränkter Haftung) supported by the Deutsche Post AG. The center is associated with the University of Bonn and offers a stimulating research environment through its research networks, research support, and visitors and doctoral programs. IZA engages in (i) original and internationally competitive research in all fields of labor economics, (ii) development of policy concepts, and (iii) dissemination of research results and concepts to the interested public. The current research program deals with (1) mobility and flexibility of labor markets, (2) internationalization of labor markets and European integration, (3) the welfare state and labor markets, (4) labor markets in transition, (5) the future of work, and (6) general labor economics.

IZA Discussion Papers often represent preliminary work and are circulated to encourage discussion. Citation of such a paper should account for its provisional character. 
IZA Discussion Paper No.2

April 1998

\section{ABSTRACT}

\section{East-West Trade and Migration: The Austro-German Case*}

Trade and migration have become more important in recent years for Austria and Germany. The transition in Central and Eastern Europe has played an important role in this development. The derived labor market consequences are not fully clear so far. This paper presents the results of econometric sectoral panel studies for both countries The Austrian findings suggest that immigration exhibits negative effects on native employment and wages, and has no effects on total employment. Imports affect employment negatively and exports have a positive effect on wages. The German results indicate that immigration and trade is not harming employment and wages. Natives seem to be complements to migrants, at least to those from East Europe. Trade does not affect wages at all, and hardly affect employment. Thus one can expect that, while the Austrian labour market might be somewhat negatively affected by the East enlargement of the EU, the German labor market will not.

JEL Classification: F14, J61, J64

Keywords: trade, immigration, labour market, employment

Klaus F. Zimmermann

IZA

P.O. Box 7240

D - 53072 Bonn

Tel.: +49-228-3894-201

Fax: +49-228-3894-210

email: Zimmermann@iza.org

* The authors thank Thomas Bauer, Ralph Rotte, Andreas Million, Anja Thalmaier and Michael Vogler for able research assistance, and conference participants, especially Riccardo Faini, for helpful comments. 


\section{Introduction}

The demise of the political system in Central and Eastern Europe and the former Soviet Union has created a new challenge for the European Union (EU) - economic integration and enlargement. Eastern enlargement concerns the association of ten Central and Eastern European countries (CEECs), the Visegrad-4 (Czech Republic, Hungary, Slovak Republic and Poland), the Balkan-3 (Bulgaria, Rumania and Slovenia), and the Baltic-3 (Estonia, Latvia and Lithuania). The integration issue, however, also covers the other states from the former Soviet Union. While enlargement is seen both as a political necessity and a historical opportunity, the economic consequences are not yet well understood. A rising number of EU member states seem more reluctant to take in new members, often because they fear that such a move will be expensive.

One major concern stems from the potential labour market effects of integration and enlargement. Opening markets will encourage factor flows and trade, and hence very likely cause adjustments in wages and employment opportunities in EU economies. Given the ever rising unemployment rates, and the relative decline of unskilled wages in Western Europe, the Eastern enlargement is seen as a threat to native labour markets. Due to geography and historical ties, Austria and Germany have already received disproportionally more immigrants and stronger increases of trade flows than other countries. It has to be expected that this trend will continue in any process of economic integration in the East. Hence, the objective of this paper is to assess present and potential future developments against the background of the Austro-German case.

Two largely separated strands of literature have investigated the effects of trade and migration on native labour markets. Labour economists have examined the hypothesis that immigration is causing a decline in wages and an increase in unemployment among natives, 
especially among low-skilled workers. However, they did not find much support for these concerns. Trade economists and labour economists have investigated the issue whether trade in particular with the developing world has caused the measured negative trends in the labour market, especially for its manual and unskilled segments. However, mostly trade economists seem to believe that this is not true but can be attributed to skill-biased technical progress. So far, only few studies deal with these issues in the European context of Eastern integration and EU enlargement.

Section 2 of the paper will survey the literature on the labour market effects of trade and migration with an emphasis on existing European, especially Austrian and German studies. Section 3 documents major trends in East-West migration and trade flows largely for Austria and Germany. Section 4 will present econometric sectoral panel studies for both countries to measure the employment and wages effects in the recent decade. Section 5 concludes.

\section{Trade, Migration and the Labour Market Consequences}

The empirical literature on labour market impacts of migration is concentrated on the U.S. experience as a major immigration country. Furthermore, NAFTA and the high U.S. trade deficit in recent years has triggered further research on trade. In many cases, both lines of research are unconnected. In the following we offer a selective review of empirical studies with a heavy concentration on European cases. (See also Zimmermann, 1995a and 1995b for a review and evaluation of European studies.) This differentiation is very important, because of the different labour market organization. Krugman (1995) paradigmatically distinguishes an "American model" from a "European model" in the way globalization interacts with the labour market. (Also Zimmermann, 1994, makes the case for a specific European migration problem.) In the more flexible U.S., wage effects should be more prominent, whereas in the European 
case unemployment effects should be more important.

U.S. immigration studies generally use regional variation in immigration as the major explanatory variable, i.e. they compare local labour markets with differing immigration rates. (As an exception, Freeman and Katz (1991) find a positive, though insignificant, association between the share of immigrants and the change in annual hours worked in an estimation for a panel of 428 U.S. industries.) LaLonde and Topel (1991) and Altonji and Card (1991) use U.S. Census data in a regional context, and both find very small unemployment effects. Borjas, Freeman and Katz (1997) use California as a prime example of a high-immigration state and compare the development of California with other states. These studies might suffer from reverse causality: immmigrants tend to concentrate in states or cities with favourable labour market conditions. Furthermore, regional out-migration (or reduced in-migration) of native workers from regions hit by migration streams might counteract the immediate impact of migration (Filer, 1992). Borjas, Freeman and Katz (1997, p. 25) are critical themselves about the spatial concept: "... spatial correlation between changes in native outcomes and immigration do not, in fact, measure what we want them to measure. The inconsistency in the signs of the correlations over time provides little information about the structural impact of immigration on the native labor market". They suggest instead to use occupations as units, but cannot apply this idea because of data problems.

This possible simultaneity bias is circumvented in historical case studies of an exogenous influx of immigrants such as the "Mariel boatlift" of Cubans to Miami in 1980 (Card, 1990) or the repatriation of French citizens from Algeria in 1962 to southern France (Hunt, 1992). Both studies find only minor transitory adaptation problems in these labour markets. In the French case the labour force rose by $1.6 \%$ in the concerned regions. In the first years significantly lower wage growth resulted as well as higher unemployment. The 
quantitative effect was modest, though. More severe negative impacts are found by Carrington and De Lima (1996) for Portuguese "Retornados" from Africa. Here labour supply rose by almost $10 \%$, and the new workers were on average highly qualified. Using comparisons with France and Spain, the authors conclude that unemployment in Portugal rose significantly between 1974 and 1980.

The situation in Austria and Germany after the fall of the iron curtain could also be considered sort of a historic experiment because of the massive inflow of immigrants and the sudden change in the trade regime. Labour market reactions to immigration and trade are especially interesting, therefore. In contrast to studies for the U.S. most studies use industries as the unit of measurement instead of regions. One reason is - of course - the smallness of the countries, another is a more rigid employment structure across industries.

$\underline{\text { Table } 1}$ summarizes recent econometric studies for Austria and Germany. Winkelmann and Zimmermann (1993) use micro panel data for Germany and the count data methodology to find detrimental effects of immigration in the 1970s on the frequency of unemployment spells. However, no negative impact for the 1980s could be detected in a later study using a panel probit approach (Mühleisen and Zimmermann, 1994). This is explained by a sufficient wage flexibility that is also obtained in the study by DeNew and Zimmermann (1994). Pischke and Velling (1993) use aggregate data for German counties. Simple regression analyses reveal high employment effects, but the effect vanishes once the mean reversion process of unemployment rates is accounted for. Hatzius (1994) uses a two-stage approach to study immigration effects in Germany. In a first stage he regresses individual unemployment on a set of region-by-period dummies and individual characteristics. He then uses the estimated coefficients in a second regression: Differentiating between foreigners, East Germans and ethnic Germans he finds no significant effect of the presence of any of these immigrant groups on unemployment 
probabilities of natives. He thereby confirms the findings of Mühleisen and Zimmermann (1994). Gang and Rivera-Batiz (1993) offer an interesting exercise in political economy: in accordance with the above mentioned studies they find that unemployment risk is not furthered by the presence of foreigners, but the individual assessment by workers is different.

Unemployed workers believe, that the presence of foreigners is responsible for their dismal situation, a belief that is not shared by employed workers.

Wage impacts are studied by DeNew and Zimmermann (1994) who use data from the German socio-economic panel together with industry concentration of foreigners. They find large negative impacts on hourly wages in a random effects panel model for blue-collar workers, but positive effects for white-collar workers. They hence conclude that foreigners are substitutes to native blue collar workers, but complements to native white collar workers. These results are corroberated by Hatzius (1994) who uses regional variation in foreign shares. More recent studies investigating wage effects include Bauer (1997) and HaiskenDeNew and Zimmermann (1997). The former contribution estimates a translog production function to calculate elasticities of complementarity, while the latter paper is an update of DeNew and Zimmermann (1994) using a longer time-series of a panel of individuals, more detailed data on immigrants and different measures of high-skilled/unskilled work. Both contributions suggest that the degree of complementarity is much more present than was found in previous exercises. Hence, immigration hardly affects native wages, at least not negative, and mostly positive.

The effect of trade on the German labor market was only investigated by Lücke (1996) and Haisken-DeNew and Zimmermann (1997). Lücke (1996) can not detect a relevant effect of the relative price of unskilled-labour intensive goods on wages. Haisken-DeNew and Zimmermann (1997) study wage and mobility effects of trade and migration to find that trade 
matters more than migration. Wages are affected negatively by a relative increase in imports (relative to exports). Trade seems to depress occupational mobility and movements within firms, but stimulates inter-firm changes.

For Austria several studies with very different methodologies exist. Pichelmann and Walterskirchen (1995) simulate increased migration using a standard Keynesian macro-model. The increased labour supply results is split up approximately equally in increased employment and unemployment. Brandel et. al. (1994) study turnover processes in firms and conclude that the recent surge of new immigrants into Austria led to a significant displacement of guestworkers of earlier generations, but also of natives: $60 \%$ of all firms in their sample with shrinking employment of natives enlarged the engagement of foreigners in the period 1989 to 1991. However, the latter study uses only descriptive techniques rather than regression analysis. Moreover, their measure of shrinking firms does not correspond exactly to the notion of displacement, because firm size can change for a variety of reasons: retirement, voluntary quits, etc. In an econometric study using individual data for workers, Winter-Ebmer and Zweimüller (1997) conclude that increased immigration did not result in higher unemployment entry of Austrian manufacturing workers, although it increased the duration of unemployment: an increase in the immigrant share by one percentage point increased unemployment duration by approximately $5 \%$, i.e. 5 days.

Wage impacts in Austria are studied by Pollan (1990) who found that the dispersion of industry wages in the period 1965-1989 was positively associated with the share of foreigners in the economy at large. Winter-Ebmer and Zweimüller's analysis (1996) concentrates on young blue-collar workers. In cross-sections wages correlate positively with foreigner shares on a regional, industry or even firm level. The pattern is more mixed in a wage growth formulation: Mobile workers - those who changed industry or region - can profit from higher 
foreign shares, whereas immobile workers lose. The authors explain these results by a bargaining model: the presence of foreign workers in a firm will reduce bargaining power of insiders because of "threat effects", on the other hand, insiders might benefit from a high share of immigrants if they are able to exploit them in a two-tier wage system.

Assessing the impact of international trade on the labour market - in line with the equilibrium character of trade theory - would ideally call for the use of a computable general equilibrium model. See e.g. Kohler (1991) for an application to trade liberalisation in Austria. (See Brown (1992) for a survey of CGE models applied to the consequences of NAFTA.) These studies typically analyse the effects ex ante rather than ex post. Some recent studies in the U.S. use simulation techniques to infer wage effects from trade (see Borjas, Freeman and Katz, 1992; Murphy and Welch (1991); Baldwin (1995) provides a survey of trade effects on employment and wages). In a recent update Borjas, Freeman and Katz (1997) attribute a significant proportion of the wage decline of U.S. high-school dropouts to increased immigration, but less to trade impacts.

Factor content studies have been heavily criticized by several authors (e.g. Wood, 1995; Bhagwati and Deheijia, 1994, or Leamer, 1996). The main problems are: (i) are trade flows the right measures or only prices, (ii) is it possible to measure the right competing groups of workers, and (iii) what unit labour coefficients should be used. Furthermore, a significant element of trade competition is a simple threat of re-location of industries abroad, which can change wages significantly without any trade flows at all (and also without any foreign direct investment flows). Rodrik (1997) argues that these effects make labour and product demand functions more elastic in the home country and labour more vulnerable to demand shifts.

For Europe only a few studies on employment effects of trade with Eastern Europe exist. Cadot and de Melo (1994) provide simulation results for the regional distribution of 
possible job creation and destruction caused by CEEC-trade with France. Looking only at emerging trade patterns with the CEECs, no general problems for EU markets as a whole as well as for specific industries, like metals or textiles, are found by a recent study edited by Faini and Portes (1995) - mainly because the level of EU-CEEC trade is still very low. The Austrian Institute of Economic Research (Aiginger, 1993) - based on industry studies - calculates a positive employment balance of Austrian trade with the CEECs. This is mainly due to higher exports as well as cheaper inputs for manufacturing firms. Aiginger, Winter-Ebmer and Zweimüller (1996) look at a panel of Austrian workers in manufacturing and conclude that individual unemployment rates over a period of three years react significantly negative to increased export volumes and (only insignificantly) positive to import volumes. However, significant positive import impacts are found for subgroups of blue-collar workers, the elderly, and low-income earners. These results are based on the period from 1988 to 1991; i.e. the immediate aftermath of the fall of the iron curtain. As the trade structure was heavily distorted before that time, these results have to be considered as transitional adaptation processes, far away from equilibrium. In any case, they have to be complemented by more recent data. By calculating the labour content of trade flows using industry-specific productivity data, Altzinger (1995) finds that increased net exports to CEEC countries have lead to positive employment effects on the Austrian labour market. For Germany Lücke (1996) analysed 32 industries in the period 1970-1992 and found that wages for unskilled labor did not react to relative price changes of unskilled-labour-intensive goods.

Apart from the relation between trade and migration, capital flows have to be considered as well. Growing foreign outward direct investments (FDI) can influence export performance significantly. The traditional Heckscher-Ohlin trade theory views FDI as export of capital motivated by higher returns abroad, and it suggests that FDI substitutes for exports, 
thus lowering the production of capital-intensive goods in the home country. Reallocation of capital in the east can be viewed in this sense as a further impediment to the employment in capital-intensive industries. This conclusion is questioned by new models with monopolistic competition and horizontally differentiated products (e.g. Helpman, 1984). If endogenous growth is based on an expanding stock of knowledge, one can show that FDI, the number of multinational firms and exports increase complementarily because of increasing product variety. Pfaffermayr (1996) tests for complementarity or substitutability of exports and FDI using a panel of Austrian industries. The results indicate a significant - although numerically small - complementarity between FDI and exports in the eighties and early nineties.

\section{East-West Flows of Goods and People}

This section investigates the flow of factors and trade between Austria and Germany and the East, and documents the performance of both countries. A summary of the economic conditions in the major countries in Central and Eastern Europe is given in Table 2, where we provide data on real growth, inflation and unemployment. The situation has improved considerably in many countries, although unemployment remains high. It seems that there is a large potential for out-migration, and trade. According to gravity models (Holzmann and Zukowska-Gagelmann, 1996) trade with Eastern Europe is still much below equilibrium projections. These expectations about trade creation have yet to be augmented by the effects of EU east enlargement.

Figure 1 studies the evolution of the foreigner share in the labour force and the import ratio (total imports divided by gross national product) for West Germany and Austria between 1986 and 1994. In total, there is a trend in favour of immigration, while the evolution of trade is stagnating. Both countries are similar in the sense that immigration and trade was expanding 
until 1990, but afterwards only the immigration level increased while the import share declined. Austria always had a higher import share, but its foreigner share was significantly below the foreigner share in Germany at the end of the eighties, before it increased to the German level in the mid-nineties. Since in the German case, immigration of ethnic Germans is not covered by the data, Figure 1 underreports this fact for Germany. Figure 2 investigates the issue using data on migrants (the share of East European workers in percent of total foreign workers) and trade from Eastern Europe (the share of imports from the East of total imports). Both shares have increased for Germany, while for Austria, the increase is only in trade. In general, Figure 2 demonstrates that Austria was and still is much more involved with the East than Germany, although this is only true in relative terms and the differences are shrinking.

\section{Austria}

Table 3a summarizes the main developments in Austria's labour market performance with respect to internationalization between 1986 and 1995. Employment rose nearly constantly, albeit on a very slow pace. Three fourth of the rise in employment were driven by increasing employment of foreign workers. The share of foreign workers almost doubled in this period, its increase was particularly high in the years 1990 and 1991. However, heavy restrictions for immigrants have damped its further development. Although the rise in foreign employment coincided with the fall of the iron curtain, most immigrants came from Austria's main sending countries, namely former Yugoslavia and Turkey. Foreign workers from Eastern Europe have only a modest share in the foreign population at large. Unemployment increased slightly over the period with constantly higher rates for foreigners than natives.

Trade with Eastern Europe was almost unchanged over the period with an export and import share of between two and three percent of domestic output. This general picture 
conceals important structural changes in terms of industries as well as terms of countries.

Whereas trade with the former Soviet Union almost collapsed, trade with the CEECs increased considerably. Moreover, the import structure changed from raw materials mainly from the Soviet Union to more refined products.

The development of foreign direct investment (FDI) is shown in Table 4. Between 1989 and 1994 Austria's outward FDI into Eastern Europe rose by more than 30-fold. The main part of these investments went into the neighbouring countries, Czechia, Slovakia and Hungary. Furthermore, in 1992 Austrian firms participated in more than $20 \%$ of all joint ventures in these countries. The high international capital inflow into Eastern Europe should lead - in principle to enhanced competition for foreign capital. This competition has not affected Austria's inward FDI's very much.

The opening of the eastern borders had regionally different impacts. Austria's northeastern parts have been suffering in the past from the dead border and the severe trade and traffic restrictions. Now, employment in the eastern parts, especially the counties in the Czech, Slovak and Hungarian borderland increased disproportionally (Geldner, 1993), whereas employment growth between 1983 and 1989 had been slow. This employment growth is completely due to new immigration. Between 1989 and 1992 foreign employment in Austria increased by $68 \%$, in the borderland by more than $200 \%$, leading the foreign share there up to the national average. Consequently, native employment stayed almost constant.

\section{Germany}

Data on migration, trade and foreign direct investment in Germany are contained in Tables $3 \mathrm{~b}$ and $\underline{4}$. Table $3 \mathrm{~b}$ indicates that employment in Germany was stagnating in recent years, between 24 and 26 million workers. However, the size of foreign employment in general has increased 
as well as the inflow of East Europeans and ethnic Germans. While the share of foreign employment was less than $8 \%$ in 1986, it reached a level of more than $9 \%$ in 1995 . The share of foreign workers from eastern Europe in percent of all foreign workers has increased from about $3 \%$ to about $8 \%$. There was a dramatic increase in the inflow of ethnic Germans per year from mids of the eighties to 1990 by a factor of ten. Since then, quotas set by the German government caused a decline to a level of somewhat about 200,000 per year. Among ethnic Germans, the inflow has more and more concentrated on migrants from Russia. While there were only less that $2 \%$ Russians among ethnic German migrants in 1986, their share increased to nearly $100 \%$ in 1995.

Native unemployment was comparatively low (less that 7\%) in the early 90s, but returned to higher levels in the middle of the 90 s (9\% as before in 1986-87). The unemployment rates of foreigners were even more rising: they have been about $14 \%$ in 1986 and were about $17 \%$ in 1995; they were then nearly twice as high as those of the natives. This increase was primarily caused by differences in job compositions (and their attached unemployment risks) between natives and foreigners, and not by higher unemployment risks of foreigners per se.

$\underline{\text { Table } 3 \mathrm{~b}}$ also suggests that trade with Eastern Europe (exports and imports) was expanding significantly both relative to domestic output and to total imports/exports. Exports and imports to and from Eastern Europe in Germany rose from about $1 \%$ of domestic output in 1986 to $1.6 \%$ in 1995 ; in terms of total imports or exports, the share rose in the same period from less than $4 \%$ to about $7 \%$.

Table 4 indicates that foreign direct investment in Eastern Europe has increased substantially over the last years; it has been 6 times higher in 1995 than it was in 1991. In contrast, German inward FDI has grown only by about $30 \%$ across the same period. However, 
the size of German FDI into eastern Europe is still somewhat modest in comparison with the Austrian involvement (its only about 2-3 times larger), and in relationship to foreign direct investment in Germany. German FDI into eastern Europe in 1994 is about 4\% of German inward FDI, whereas the same number for Austria is $11 \%$.

\section{Effects on the Labour Markets}

In this section, we investigate the effects of immigration change and export and import flows on employment and wage growth. Employment growth is also studied for natives only. The time period chosen is 1986-1994 to cover a period before and after the demise of the socialist system. We use all available sectors at the two-digit ISCO level excluding those that have no international trade. The data sets have a panel structure. The Austrian sample is somewhat larger, since we obtained a more complete set of information in this country. Due to data problems and different structural issues, the model specification differs somewhat between both countries. We employ a reduced form approach where growth rates of (total and native) employment and wages depend on a time trend and various measures of changes of foreigner shares and trade shares. The basic method is weighted regression, where we use the sectoral employment shares as weights. The migration flows are instrumented to capture endogeneity problems. The instruments were only valid for migration flows, and hence were not applied for the other regressors.

\section{Austria}

The data for Austria capture 30 industries for the years 1985-1994. Employment and wage statistics were obtained from the Ministry of Labor. Contrary to Germany, the number of immigrant workers is not differentiated between those from Eastern Europe and elsewhere. As 
most immigrants to Austria are from the former Yugoslavia and from Turkey, the human capital as well as the language knowledge of these immigrants can be assumed to be similar to that of the more recent immigrants from Eastern Europe. As an indicator for wage growth we take the median monthly gross wage in the industry. Trade shares are nominal exports (imports) divided by nominal output in the industry; which in fact assumes equal price indices for imports and domestically produced goods. As the bulk of manufactured goods trade with Eastern Europe took place with former Czecho-Slovakia, Hungary and Poland, the Eastern trade measures in the Austrian regressions use only these three (four) countries. As trade data use the SITC nomenclature, while the labour market data apply the ISIC code, we had to use a concordance which was developed by the Austrian Institute of Economic Research; this concordance defines which ISIC code is nearest to an SITC code at the three-digit level.

Results for the reduced form regressions for employment and wage growth are in

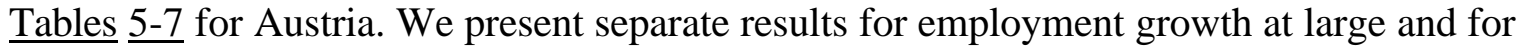
employment of domestic workers. As the pooled time-series cross-section approach assumes constant coefficients for all industries, we study also some subsamples, who might be more endangered by increasing internationalisation. Immigrant shares are instrumented by industry minimum wages, shares of blue-collar workers and EU output growth.

Immigration is found to have no impact on industry employment at large. This is equally so for the 3 subsamples we study. In contrast to that, rising import penetration has employment costs. Interestingly, this applies mainly to imports form Eastern Europe. The quantitative impact is relatively low: a $1 \%$ increase in the import share leads to reduced employment by $0.03 \%$. It has to be noticed that this elasticity applies to a very low import share of Eastern firms. The elasticity is somewhat higher in low-wage industries and especially in industries characterized by a high share of foreign workers. For these subgroups, rising imports from 
ROW countries have also detrimental employment effects. Exports are never significant. Domestic industry output growth has always the expected positive employment impact, although with a rather small elasticity.

This pattern is very similar for domestic employment growth, but we can see that a rising foreigner share with practically constant total employment will reduce domestic employment. A $1 \%$ increase in the foreigner share in industry employment reduces domestic employment by $0.13 \%$. This means that increasing immigration led almost to a complete displacement of native workers in the concerned industries, with the highest effects in highimmigration industries. Again imports from Eastern Europe have a minor negative employment effect and ROW imports are only significant in low-wage industries.

Wages react negatively to increased immigration with an elasticity of 0.16 . The wagedepressing effects are lower in already low-wage industries and insignificant in industries with high-import as well as immigration shares. This might be explained by a higher tendency for binding minimum wages in low-wage industries. Other explanations would refer to a higher potential of rent-reductions in high-wage and often more unionized industries. Freeman and Katz (1991) for instance find for the U.S. that wage responsiveness was higher in high-wage and high-unionized sectors. Industry wage growth is not affected by rising imports. This corroborates results by Gaston and Trefler (1994) who study the Canadian employment and wage reaction to increased trade with the U.S. in a very similar framework than ours. Contrary to employment reactions, exports into ROW countries significantly further wage growth, with an elasticity of 0.24 and an even higher response rate in high-immigrant industries. As we observe only median wages for Austria, this differing response could be the result of a structural employment effect: the creation of relatively high-paying jobs in export industries. These issues can only be resolved by the use of more detailed data on income distribution 
within industries and is beyond the scope of the present study. Again, output growth has a significant positive wage impact.

\section{Germany}

Results for Germany are given in Tables 8 to $\underline{10}$ for 12 industries in 1987-1994. Where ever possible, the data refers to Western Germany, and the exceptions will be notified below. The regressions contain a time trend, output growth (measured as real gross value added in percent), and various growth rates of foreigner shares in the labour force and growth rates of export and import ratios. Wage, output, employment and trade data are from various sources of the German statistical office. Numbers on workers from Eastern Europe are from a recent report of the Council of Economic Experts, and the figures on ethnic Germans are from a government report.

The growth rate of the foreigner share in the labour force is the change of foreign workers to the total change in the labour force. A separate term for the Eastern Europe workers in the labour force allows for a examination of the hypothesis whether this group of workers has effects different from the general group of foreigners. If they behave equally, the estimated coefficient for the East Europeans should not be statistically different from zero. While the total foreigner share in the labour force is differentiated according to industry, the employment of East Europeans is not available at the industry level. Hence, we have distributed the East Europeans using sectoral employment shares of the workers from the former Yugoslavia assuming that the employment structure is similar.

The inflow of ethnic Germans in the labour market is not properly recorded. This is because the only statistic available is the total inflow of ethnic Germans according to sending regions. Since they immediately obtain the German citizenship, they disappear in the German 
statistic; there are no records about their labour force participation and their sectoral involvement. Hence, we approximate the percentage change of the share of ethnic Germans in the labour force by the difference between (i) the inflow of ethnic Germans divided by lagged total employment and (ii) the growth rate of employment.

Import and export data are collected on a somewhat different classification scheme, but can be merged with sufficient precision. Imports and exports are measured in unit values, but are only available either on an industry breakdown (and not differentiated by regions) or differentiated for sending regions (but not disaggregated at the industry level). Hence, we decided to include variables that capture both levels of measurement. The import and export data at the sectoral levels were divided by the sectoral outputs (real gross value added), respectively. We also included (real) total imports and exports from East Europe divided by the real gross domestic product. A further problem is that imports and exports after unification are not differentiated according to Western and Eastern Germany. This is not too much of an issue since most of the trade seems to take place with Western Germany.

The regressions for employment growth, native employment growth and wages are contained in Table 8 to $\underline{10}$. All regressions are weighted with the industry employment shares, and migration flows are instrumented as detailed in the footnotes of the tables. As for the Austrian case, each table contains results for all industries and for those industries with low wages, high imports and many foreigners.

$\underline{\text { Table } 8}$ refers to total employment growth that is largely driven by output growth in all samples, where all the estimated parameters have large t-ratios, while the trend variable is hardly significant at conventional levels. There are no clear indications that immigration has affected total employment negatively. However, a clear negative effect (with significant tvalues for low-wage and high-import industries only) were obtained for Russian ethnic German 
immigrants, while an increase in the foreigner share from Eastern Europe has exhibited a positive (and mostly significant) effect on total employment. The total foreigner share is statistically significant only for high import industries with a positive parameter estimate. All import shares affect employment positively, and exports negatively, although not always with statistically significant t-values.

$\underline{\text { Table } 9}$ contains the same set of regressors, but using native employment growth as the dependent variable. Again, output growth is driving employment, and the time trend plays no effective role. However, the general foreigner share now exhibits a negative coefficient in three out of four cases (with the exception of high import industries), and the negative parameters are even significant for low wages and high immigration industries. East European immigration does not exhibit much of a relevant additional contribution. Global trade shows up with the signs of the parameters as before; they are all positive for imports and negative for exports, but only few are statistically significant. In addition, all East European trade variables have insignificant parameter estimates.

$\underline{\text { Table } 10}$ studies wage growth, which again depends largely on output growth and is unaffected by the time trend. Here, foreigners (especially East Europeans) seem to have a positive effect on general wages, but the estimates are only significant in a few cases; for high immigration industries and the growth rate of the general foreigner share; for high import industries (and the total sample) and the growth rate of the East European foreigner share. Finally, none of the trade variables have any significant impact on wage growth.

The simple labour market model would suggest that more foreigners should depress wages (if migrants are substitutes to natives), and increase total employment while native employment should remain constant (if markets are flexible). In the findings reported here, wages do not decline, at best they are increasing (especially if related to the inflow of East 
Europeans). Total employment is increasing, although mainly due to East Europeans. Native employment is somewhat (and negatively) affected by foreigners in general, but positively by East Europeans. This all suggests that East Europeans and German workers are complements, and that the overall effect of migrants on the German labor market is unproblematic.

The results for the trade variables are also controversial. Traditional theory would expect a positive impact of exports on employment and wages, and the reverse for import. Trade does not affect wages at all, perhaps because one should differentiate wages for qualification levels and trade for regions to obtain more sensible findings, but we cannot do this due to lack of data. In the employment equations, imports (exports) have a negative (positive) impact on employment, but the estimates are in most cases statistically insignificant. This can be explained by the relationship of trade to technical progress, which is insufficiently measured by the time trend. It is well known that technical progress is more intense in exporting industries, while importing industries are less innovative. Hence, we may be unable to separate these effects. In sum, we cannot find harming effects of trade on the German labor market.

\section{$\underline{\text { 5. Conclusions }}$}

Trade and migration have become more important in recent years for Austria and Germany. The transition in Central and Eastern Europe has played an important role in this development. The derived labour market consequences are not fully clear so far. The Austrian findings suggest that immigration exhibits negative effects on native employment and wages, and has no effects on total employment. Imports affect employment negatively and exports have a positive effect on wages. The German results indicate that immigration and trade is not harming employment and wages. Natives seem to be complements to migrants, at least to those from East Europe. Trade does not affect wages at all, and hardly affect employment. These results 
are in line with recent findings for both Austria and Germany. Hence the conclusions are: While the Austrian labour market might be somewhat negatively affected by the East enlargement of the EU, the German labour market is not. Further research and better data is needed to understand this finding properly. 


\section{References}

Aiginger, Karl, Winter-Ebmer, Rudolf and Josef Zweimüller: Eastern European Trade and the Austrian Labor Market, Weltwirtschaftliches Archiv 132, 1996, 476-500.

Aiginger, Karl: Chancen und Gefährdungspotentiale der Ostöffnung, Austrian Institute for Economic Research, Wien, 1993.

Altonji, Joseph G. and David Card: The Effects of Immigration on the Labor Market Output of Less-skilled Natives, in: Abowd, John M. and Richard B. Freeman (eds.), Immigration, Trade, and the Labor Market, Chicago (University of Chicago Press for NBER), 1991, 201-234.

Altzinger, Wilfried, Beschäftigungseffekte des österreichischen Osthandels, Working Paper No.34, Department of Economics, Vienna University of Economics and Business Administration, 1995, Vienna.

Baldwin, Richard E.: The Effect of Trade and Foreign Direct Investment on Employment and Relative Wages, NBER Working Paper \# 5037, 1995.

Bauer, Thomas: Native Wage Impacts of Foreign Labor: Further Evidence for Germany, forthcoming in: Mitteilungen zur Arbeitsmarkt- und Berufsforschung, 1997.

Bhagwati, Jagdish and Vivek H. Dehejia: Freer Trade and Wages of the Unskilled - Is Marx Striking Again?, in: Bhagwati, Jagdish and Marvin H. Kosters (eds.), Trade and Wages: Leveling Wages Down?, Washington (American Enterprise Institute), 1994.

Borjas, George J., Freeman, Richard B. and Lawrence H. Katz: On the Labor Market Effects of Immigration and Trade, in: Borjas, George J. and Richard B. Freeman (eds.), Immigration and the Work Force, Chicago (University of Chicago Press), 1992, 213 244. 
Borjas, George J., Freeman, Richard B. and Lawrence H. Katz: How much do Immigration and Trade Affect Labor Market Outcomes, Brookings Papers on Economic Activity 1/1997, 1-90.

Brandel, Franz, Hofer, Helmut and Karl Pichelmann: Verdrängungsprozesse am Arbeitsmarkt, Research Memorandum No. 345, Institute for Advanced Studies, Vienna, 1994.

Brown, Drusilla K.: The Impact of North American Free Trade Agreement: Applied General Equilibrium Models, in: Nora Lustig et al (eds.): North American Free Trade: Assessing the Impact, Washington, D.C. (The Brookings Institution), 1992.

Cadot, Olivier and Jaime de Melo: France and the CEECs: Adjusting to another Enlargement, mimeo, INSEAD, paper presented to a CEPR Conference, Brussels, 1994.

Card, David: The Impact of the Mariel Boatlift on the Miami Labor Market, Industrial and Labor Relations Review 43, 1990, 245-257.

Carrington, William I. and Pedro de Lima: The Impact of 1970's Repatriates from Africa on the Portuguese Labor Market, Industrial and Labor Relations Review 49, 1996, 330347.

De New, John P. and Klaus F. Zimmermann: Native Wage Impacts of Foreign Labor: A Random Effects Panel Analysis, Journal of Population Economics 7, 1994, 177-192. Sachverständigenrat: Jahresgutachten 1996/97 des Sachverständigenrates zur Begutachtung der gesamtwirtschaftlichen Entwicklung, Bundestagsdrucksache 13/6200, Bonn, 1996. Sachverständigenrat: Jahresgutachten 1997/98 des Schverständigenrates zur Begutachtung der gesamtwirtschaftlichen Entwicklung, Bundestagsdrucksache 13/9090, Bonn, 1997. Faini, Riccardo and Richard Portes (eds.): European Union Trade with Eastern Europe: Adjustment and Opportunities, London (Centre for Economic Policy Research), 1995. Filer, Randall K.: The Effect of Immigrant Arrivals on Migratory Patterns of Native Workers, 
in: Borjas, George J. and Richard B. Freeman (eds.), Immigration and the Work Force, Chicago (University of Chicago Press), 1992, 245-270.

Freeman, Richard B. and Lawrence F. Katz: Industrial Wage and Employment Determination in an Open Economy, in: Abowd, John M. and Richard B. Freeman (eds.), Immigration, Trade and the Labor Market, Chicago (University of Chicago Press), 1991, 235-260.

Gang, Ira N. and Rivera-Batiz, Francisco L.: Unemployment and Attitudes against Foreigners in Germany, mimeo, Rutgers University, 1993.

Geldner, Norbert: Beschäftigungseffekte der Ostöffnung, in: Aiginger Karl (ed.): Chancen und Gefährdungspotential der Ostöffnung, Wien (Wirtschaftsforschungsinstitut), 1993, 4146.

Haisken-De New, John P. and Klaus F. Zimmermann: Wage and Mobility Effects of Trade and Migration, forthcoming in: W. Dewatripont and A. Sapir (eds.), International Trade and Employment: The European Experience, (Oxford University Press), 1997.

Hatzius, Jan: The Unemployment and Earnings Effects of German Immigration, mimeo, Merton College, Oxford, 1994.

Helpman, Elhanan: A Simple Theory of International Trade with Multinational Corporations, Journal of Political Economy 92, 1984, 451-471.

Holzmann, Robert and Katarzyna Zudowska-Gagelmann: Exportchancen und Importschocks: Eine Untersuchung zur Asymmetrie der Handelsanpassung der OECD-Länder im Gefolge der Marktöffnung in Mittel- und Osteuropa, in: Holzmann, Robert and Reinhard Neck (eds.), Ostöffnung: Wirtschaftliche Folgen für Österreich, Vienna (Manz), 1996, 193-236.

Hunt, Jennifer: The Impact of the 1962 Repatriates from Algeria on the French Labor Market, 
Industrial and Labor Relations Review 45, 1992, 556-572.

Krugman, Paul: Growing World Trade: Causes and Consequences, Brookings Papers on Economic Activity, 1995, 259-377.

Kohler, Wilhelm: Multilateral Trade Liberalization: Some General Equilibrium Simulation Results for Austria, Empirica 18, 1991, 167-200.

LaLonde, Robert J. and Robert H. Topel: Labor Market Adjustments to Increased Immigration, in: Abowd, John M. and Richard B. Freeman (eds.), Immigration, Trade, and the Labor Market, Chicago (University of Chicago Press for NBER), 1991, 167200.

Leamer, Edward E.: What's the Use of Factor Contents? NBER WP \# 5448, 1996.

Lücke, Mathias: Has Trade with Low-Wage Countries Hurt Unskilled Labour in West Germany?, mimeo, Kiel (Insitute of World Economics), 1996.

Mühleisen, Martin and Klaus F. Zimmermann: A Panel Analysis of Job Changes and Unemployment, European Economic Review, 38, 1994, 793-801.

Murphy, Kevin M. and Finis Welch: The Role of International Trade in Wage Differentials, in: Kosters, Marvin H. (ed.), Workers and their Wages, Washington D.C. (American Enterprise Institute), 1991.

Pfaffermayr, Michael: Foreign Outward Direct Investment and Exprts in Austrian Manufacturing: Substituts or Complements, Weltwirtschaftliches Archiv 132, 1996, $501-522$.

Pichelmann, Karl and Edwald Walterskirchen: East-West Integration and its Impact on Workers: The Austrian example, Institute for advanced studies, reprint \# 14, Vienna, 1995.

Pischke, Jörn-Steffen and Johannes Velling: Ausländische Werkvertragsarbeitnehmer am Bau: 
Bauboom oder Verdrängungswettbewerb, ZEW Discussion Paper 9315, Mannheim, 1993.

Pischke, Jörn-Steffen and Johannes Velling: Labor Market Effects of Foreign Employment in Germany, CEPR WP \# 935, 1994.

Pollan, Wolfgang: Lohnunterschiede in der Industrie, Monatsberichte des Österreichischen Instituts für Wirtschaftsforschung 63, 1990, 616-622.

Rodrik, Dani: Has Globalization Gone Too Far? Washington (Institut for International Economics), 1997.

Winkelmann, Rainer and Klaus F. Zimmermann: Ageing, Migration and Labour Mobility, in: Johnson, Paul and Klaus F. Zimmermann (eds.): Labour Markets in an Ageing Europe, (Cambridge University Press), 1993, 255-283.

Winter-Ebmer, Rudolf and Josef Zweimüller: Immigration and the Earnings of Young Native Workers, Oxford Economic Papers 48, 1996, 473-491.

Winter-Ebmer, Rudolf and Josef Zweimüller: Immigration, Trade and Austrian Unemployment, forthcoming in: Landesmann, Michael and Erich Streissler (eds.), Unemployment in Europe, London (MacMillan), 1997.

Wood, Adrian, How Trade Hurts Unskilled Works: Journal of Economic Perspectives 9, 5780.

Zimmermann, Klaus F.: Some General Lessons for Europe's Migration Problem, in: H. Giersch (ed.), Economic Aspects of International Migration, Heidelberg et. al. (SpringerVerlag), 1994, 249-273.

Zimmermann, Klaus F.: European Migration: Push and Pull, Proceedings volume of the World Bank Annual Conference on Development Economics 1994, Supplement to The World Bank Economic Review and The World Bank Research Observer, 1995, 313-342, 
reprinted in: International Regional Science Review 19, 1996, 95-128.

Zimmermann, Klaus F.: Tackling the European Migration Problem, Journal of Economic

Perspectives 9, 1995, 45-62, reprinted 1998 in: M. N. Jovanovic (ed.), International Economic Integration. Critical Perspectives of the World Economy, London (Routledge). 
Table 1: Empirical Studies on the Effects of Trade and Migration on the Labour Market in Austria and Germany

\begin{tabular}{|c|c|c|c|}
\hline Authors & $\begin{array}{l}\text { Data, methods and dependent } \\
\text { variables }\end{array}$ & Time period & Findings \\
\hline \multicolumn{4}{|l|}{ A: Austria } \\
\hline Aiginger, Winter-Ebmer and Zweimüller (1996) & $\begin{array}{l}\text { social security records, manufacturing } \\
\text { workers, individual } \\
\text { unemployment rate, } \Delta \mathrm{w}\end{array}$ & 1988-1991 & $\begin{array}{l}\mathrm{u}: \text { exports }(-), \text { imports }(\sim) \\
\Delta \mathrm{W} \text { : exports }(+), \operatorname{imports}(\sim)\end{array}$ \\
\hline Pichelmann and Walterskirchen (1995) & macro model & & u: migrant share $(+)$ \\
\hline Pollan (1990) & $\begin{array}{l}\text { aggregate time series, } \\
\text { wage dispersion }(\sigma(\mathrm{w}))\end{array}$ & 1965-1989 & $\sigma(w)$ : migrant share $(+)$ \\
\hline Winter-Ebmer and Zweimüller (1996) & $\begin{array}{l}\text { social security records, young workers, } \\
\text { w, } \Delta \mathrm{W}\end{array}$ & 1981-1991 & $\begin{array}{l}\text { w: migrant share }(+) \\
\Delta \mathrm{w} \text { : migrant share }(\sim)\end{array}$ \\
\hline Winter-Ebmer and Zweimüller (1997) & $\begin{array}{l}\text { social security records, manufacturing } \\
\text { workers, } \\
\text { unemployment risk, duration }\end{array}$ & 1988-1991 & $\begin{array}{l}\text { u risk: migrant share }(\sim), \\
\text { imports }(\sim) \text {, exports }(\sim) \\
\text { u duration: migrant share }(+) \text {, } \\
\text { imports }(\sim) \text {, export share }(\sim)\end{array}$ \\
\hline
\end{tabular}


Table 1 continued:

\section{B: Germany}

Bauer (1997)

DeNew and Zimmermann (1994)

Haisken-DeNew and Zimmermann (1997)

Hatzius (1994)

Lücke (1996)

Mühleisen and Zimmermann (1994)

Pischke and Velling (1994)

Winkelmann and Zimmermann (1993)
German labour force survey, estimation

of a translog production function; wages

German socio-economic panel (SOEP), micro panel with sectoral migrant

share; wages (w)

SOEP, panel with migrant share differenciated according to industry and state (Bundesländer); wages (w) and mobility (m)

regional migrant share

32 industries

$\mathrm{w}$ for unskilled labour

SOEP, individual unemployment, sectoral migrant shares

county data, unemployment rate

SOEP, unemployment risk, sectoral migrant share
1984-1989

1984-1992

$+2$

Small elasticities of complementarity. Most of the immigrant groups are complements to natives.

w: migrant labour share total (-),

blue collar (-), white collar (+)

w: migrant labour share (+)

trade deficit ratio (-)

m: migrant labour share $(\sim)$

trade deficit ratio $(-)$

w: migrant share (-)

$\mathrm{u}$ : migrant share $(\sim)$

1970-1992

w: relative price of unskilled-labour-intensive goods $(\sim)$

1984-1989

u risk: migrant labour share $(\sim)$

1985-1989

$\mathrm{u}$ : $\Delta$ migrant population share $(\sim)$

1974-1984

Key to notation:

(+) the coefficient is positive and significant in most reported specifications

$(-)$ the coefficient is negative and significant in most reported specifications

$(\sim)$ the coefficient has mixed sign or is not significant in most specifications 
Table 2: Economic Development in Central and Eastern Europe ${ }^{\mathrm{a}}$

\begin{tabular}{|c|c|c|c|c|c|c|c|c|}
\hline & $\begin{array}{c}\text { Polan } \\
\text { d } \\
\end{array}$ & $\begin{array}{c}\text { Czech } \\
\text { Republic }\end{array}$ & $\begin{array}{c}\text { Slowaki } \\
\text { a }\end{array}$ & $\begin{array}{c}\text { Hungar } \\
\mathrm{y} \\
\end{array}$ & Slovenia & Rumania & $\begin{array}{c}\text { Bulgari } \\
\text { a } \\
\end{array}$ & Russia \\
\hline \multicolumn{9}{|c|}{ Real Growth } \\
\hline 1991 & -7.0 & -14.2 & -11.2 & -11.9 & -9.3 & -12.9 & -11.7 & -5.0 \\
\hline 1992 & 2.6 & -3.3 & -6.5 & -3.1 & -5.5 & -8.8 & -7.3 & -14.5 \\
\hline 1993 & 3.8 & -0.6 & -3.7 & -0.6 & 2.8 & 1.5 & -1.5 & -8.7 \\
\hline 1994 & 5.2 & 2.6 & 4.9 & 2.9 & 5.3 & 3.9 & 1.8 & -12.6 \\
\hline 1995 & 7.0 & 4.8 & 6.8 & 1.5 & 3.9 & 7.1 & 2.1 & -4.0 \\
\hline 1996 & 6.1 & 4.4 & 7.0 & 1.1 & 3.5 & 4.1 & -10.9 & -2.8 \\
\hline 1997 & 5.5 & 1.0 & 5.0 & 3.0 & 3.5 & -2.0 & -7.0 & 0.5 \\
\hline \multicolumn{9}{|c|}{ Inflation } \\
\hline 1991 & 76.5 & 56.7 & 61.1 & 34.8 & 115.2 & 174.4 & 338.5 & 93.0 \\
\hline 1992 & 43.0 & 11.1 & 10.0 & 23.0 & 201.3 & 210.4 & 91.2 & 1526.6 \\
\hline 1993 & 35.3 & 20.8 & 23.2 & 22.5 & 32.3 & 256.1 & 72.8 & 873.5 \\
\hline 1994 & 33.2 & 10.0 & 13.4 & 18.9 & 19.8 & 136.8 & 96.0 & 307.6 \\
\hline 1995 & 27.8 & 9.0 & 9.9 & 28.2 & 12.6 & 32.3 & 62.1 & 197.5 \\
\hline 1996 & 19.9 & 8.8 & 5.8 & 23.5 & 9.7 & 38.8 & 123.0 & 47.6 \\
\hline 1997 & 16.0 & 9.0 & 6.5 & 18.0 & 9.0 & 150.0 & 1100.0 & 15.0 \\
\hline \multicolumn{9}{|c|}{ Unemployment } \\
\hline \multicolumn{9}{|l|}{ Rate } \\
\hline 1991 & 9.2 & 2.8 & 7.1 & 5.4 & 8.2 & - & 11.1 & - \\
\hline 1992 & 12.9 & 3.0 & 11.3 & 10.7 & 11.5 & 6.2 & 13.2 & 0.4 \\
\hline 1993 & 14.9 & 3.0 & 12.9 & 12.8 & 14.4 & 9.2 & 16.3 & 1.0 \\
\hline 1994 & 14.4 & 3.2 & 14.8 & 10.8 & 9.1 & 10.9 & 12.8 & 6.0 \\
\hline 1995 & 13.3 & 3.1 & 13.1 & 10.3 & 7.4 & 8.9 & 10.8 & 8.0 \\
\hline 1996 & 12.4 & 3.5 & 12.5 & 10.0 & 7.3 & 8.5 & 12.5 & 9.0 \\
\hline 1997 & 11.5 & 4.5 & 12.5 & 9.0 & 7.0 & 10.0 & 14.0 & 10.0 \\
\hline
\end{tabular}

Source: Sachverständigenrat (1996/97), p. 33 and Sachverständigenrat (1997/98), p. 30.

a Real growth: Gross domestic product; inflation: consumer price index. All numbers in per cent. 1997:

Estimates of the German Council of Economic Experts. 
Table 3a: Labour, Migration and Trade: Austria

\begin{tabular}{|c|c|c|c|c|c|c|c|c|c|c|}
\hline & 1986 & 1987 & 1988 & 1989 & 1990 & 1991 & 1992 & 1993 & 1994 & 1995 \\
\hline Employment ('000) & 2,780 & 2,785 & 2,765 & 2,815 & 2,881 & 2,940 & 2,964 & 2,956 & 2,972 & 2,970 \\
\hline Unemployment rate natives (\%) & 5.2 & 5.6 & 5.3 & 5.0 & 5.4 & 5.8 & 5.9 & 6.8 & 6.5 & 6.6 \\
\hline $\begin{array}{l}\text { Unemployment rate foreigners } \\
(\%)\end{array}$ & 6.4 & 5.7 & 6.2 & 5.9 & 7.8 & 7.1 & 8.6 & 9.1 & 8.3 & 7.9 \\
\hline Foreign share in employment (\%) & 5.2 & 5.3 & 5.4 & 5.8 & 7.2 & 8.6 & 9.0 & 9.0 & 9.5 & 9.8 \\
\hline $\begin{array}{l}\text { Foreign workers from former } \\
\text { Yugoslavia in } \% \text { of all foreigners }\end{array}$ & 57.3 & 55.9 & 55.0 & 54.2 & 50.7 & 48.5 & 49.6 & 50.6 & 48.9 & 50.7 \\
\hline $\begin{array}{l}\text { Foreigners from Eastern Europe } \\
\text { in } \% \text { of all foreigners }\end{array}$ & $3.0^{\mathrm{b}}$ & - & - & - & 14.5 & 14.7 & 15.6 & 15.1 & 14.7 & 14.1 \\
\hline $\begin{array}{l}\text { Eastern-Europe-exports in \% of } \\
\text { domestic output }\end{array}$ & 2.69 & 2.41 & 2.57 & 2.66 & 2.51 & 2.57 & 2.64 & 2.65 & 2.86 & - \\
\hline $\begin{array}{l}\text { Eastern-Europe-imports in } \% \text { of } \\
\text { domestic output }\end{array}$ & 2.77 & 2.19 & 2.11 & 2.14 & 2.12 & 2.13 & 2.15 & 2.07 & 2.41 & - \\
\hline $\begin{array}{l}\text { Eastern-Europe-exports in } \% \text { of } \\
\text { total exports }\end{array}$ & 9.63 & 9.02 & 9.14 & 9.04 & 8.84 & 8.98 & 9.68 & 10.48 & 11.00 & - \\
\hline $\begin{array}{l}\text { Eastern-Europe-imports in } \% \text { of } \\
\text { total imports }\end{array}$ & 8.34 & 6.80 & 6.37 & 6.06 & 6.00 & 6.04 & 6.47 & 6.76 & 7.54 & - \\
\hline
\end{tabular}

a Excluding workers from Ex-Yugoslavia, which is the major sending country for Austria. b 1981.

Source: Statistisches Handbuch der Republik Österreich, various years, WIFO Data base, Vienna. Employment according to Hauptverband der Sozialversicherungsträger, excluding those below the minimum social security contributions level. 
Table 3b: Labour, Migration and Trade: Germany

\begin{tabular}{lcccccccccc}
\hline & 1986 & 1987 & 1988 & 1989 & 1990 & 1991 & 1992 & 1993 & 1994 & 1995 \\
\hline Employed workers ('000) & 23,910 & 24,141 & 24,365 & 24,750 & 25,460 & 25,920 & 26,066 & 25,611 & 25,242 & 25,022 \\
Unemployment rate natives (\%) & 9.0 & 8.9 & 8.7 & 7.9 & 7.2 & 6.3 & 6.6 & 8.2 & 9.2 & 9.3 \\
Unemployment rate foreigners (\%) & 13.7 & 14.3 & 14.4 & 12.2 & 10.9 & 10.7 & 12.2 & 15.1 & 16.2 & 16.6 \\
Foreign share in employment (\%) & 7.7 & 7.6 & 7.6 & 7.8 & 8.0 & 8.2 & 8.7 & 9.5 & 9.4 & 9.4 \\
Foreign workers from Eastern & 2.9 & 3.1 & 3.4 & 3.8 & 4.2 & 5.5 & 7.3 & 8.1 & 7.7 & 7.8 \\
Europe in \% of all foreign workers & & & & & & & & & & \\
Inflow of ethnic-Germans ('000) & 42.7 & 78.5 & 202.6 & 377.0 & 397.1 & 222.0 & 230.5 & 218.9 & 222.6 & 217.9 \\
Inflow of ethnic-Germans from & 1.76 & 18.5 & 23.5 & 26.0 & 37.0 & 66.4 & 84.9 & 94.7 & 95.8 & 96.1 \\
Russia in \% of total inflow & & & & & & & & & & \\
Eastern-Europe-exports in \% of & 1.04 & 0.90 & 1.00 & 1.17 & 1.03 & 1.36 & 0.81 & 1.40 & 1.51 & 1.62 \\
domestic output & & & & & & & & & & \\
Eastern-Europe-imports in \% of & 0.99 & 0.80 & 0.81 & 0.90 & 0.91 & 1.15 & 0.78 & 1.14 & 1.36 & 1.62 \\
domestic output & & & & & & & & & & \\
Eastern-Europe-exports in \% of & 3.45 & 3.13 & 3.39 & 3.71 & 3.21 & 5.36 & 3.42 & 6.30 & 6.60 & 6.85 \\
total exports & & & & & & & & & & \\
Eastern-Europe-imports in \% of & 3.96 & 3.36 & 3.33 & 3.44 & 3.46 & 4.53 & 3.27 & 5.29 & 6.11 & 7.11 \\
total imports & & & & & & & & & & \\
\hline
\end{tabular}

Source: Statistisches Bundesamt, Statistisches Jahrbuch, various years; Fachserie 18, 1.3, various years; Sachverständigenrat (1996). 
Table 4: Foreign Direct Investment (FDI, Stocks in Mio ECU)

\begin{tabular}{lccccccc}
\hline & 1989 & 1990 & 1991 & 1992 & 1993 & 1994 & 1995 \\
\hline Austria & & & & & & & \\
FDI into Eastern Europe & 47.6 & 240.7 & 516.9 & 733.9 & $1,043.2$ & $1,558.0$ & - \\
Austrian inward FDI & - & - & 12,137 & 12,028 & 13,230 & 14,408 & - \\
Germany & & & & & & & \\
FDI into Eastern Europe & - & - & 1,076 & 1,857 & 3,312 & 4,864 & 6,599 \\
German inward FDI & 71,493 & 83,089 & 93,986 & 96,812 & 105,517 & 113,432 & 122,284 \\
\hline
\end{tabular}

Source: Mitteilungen des Direktoriums der Österreichischen Nationalbank, various years; Statistisches Jahrbuch für die Bundesrepublik Deutschland, various years; Sachverständigenrat (1996). Own calculations. 
Table 5: Employment Growth: Austria ${ }^{\mathrm{a}}$

\begin{tabular}{lcccc}
\hline & $\begin{array}{c}\text { All } \\
\text { industries }\end{array}$ & $\begin{array}{c}\text { Low-wage } \\
\text { industries }\end{array}$ & $\begin{array}{c}\text { High-import } \\
\text { industries }\end{array}$ & $\begin{array}{c}\text { High- } \\
\text { immigration } \\
\text { industries }\end{array}$ \\
\hline$\Delta \ln$ (Foreign share) & -0.001 & -0.031 & -0.042 & -0.030 \\
$\Delta \ln ($ East-import share) & $-0.04)$ & $(0.87)$ & $(1.12)$ & $(0.88)$ \\
& $(2.59)$ & -0.045 & -0.019 & -0.076 \\
$\Delta \ln ($ ROW-import share) & -0.055 & -0.150 & 0.049 & $(3.05)$ \\
& $(1.25)$ & $(1.91)$ & $(0.89)$ & -0.172 \\
$\Delta \ln$ (East-export share) & -0.011 & -0.009 & 0.016 & 0.001 \\
& $(0.98)$ & $(0.40)$ & $(1.27)$ & $(0.02)$ \\
$\Delta \ln$ (ROW-export share) & -0.038 & -0.001 & -0.039 & -0.038 \\
& $(1.02)$ & $(0.02)$ & $(0.85)$ & $(0.54)$ \\
$\Delta \ln ($ Output) & 0.268 & 0.328 & 0.394 & 0.276 \\
& $(5.90)$ & $(4.73)$ & $(7.51)$ & $(3.76)$ \\
Time trend & -0.001 & 0.001 & -0.002 & 0.001 \\
& $(0.40)$ & $(1.08)$ & $(1.66)$ & $(0.64)$ \\
$\mathrm{R}^{2}$ & 0.232 & 0.255 & 0.279 & 0.282 \\
$\mathrm{~F}$ & 11.33 & 7.22 & 8.05 & 8.13 \\
$\mathrm{~N}$ & 240 & 128 & 128 & 128 \\
\hline
\end{tabular}

a All regressions include a constant. Absolute t-values in parentheses. Regressions weighted by employment share. Time period 1987-1994. $\Delta \ln$ (Foreign share) is instrumented. Instruments are lagged levels and changes in minimum wages, shares of blue-collar workers and EU output as well as lagged levels of immigrant shares. Low-wage industries refers to those with a mean wage level 87-94 up to the industry median; respectively for high-import and high-immigration. 
Table 6: Native Employment Growth: Austria ${ }^{\mathrm{a}}$

\begin{tabular}{lcccc}
\hline & $\begin{array}{c}\text { All } \\
\text { industries }\end{array}$ & $\begin{array}{c}\text { Low-wage } \\
\text { industries }\end{array}$ & $\begin{array}{c}\text { High-import } \\
\text { industries }\end{array}$ & $\begin{array}{c}\text { High- } \\
\text { immigration } \\
\text { industries }\end{array}$ \\
\hline$\Delta \ln$ (Foreign share) & -0.131 & -0.143 & -0.148 & -0.183 \\
$\Delta \ln ($ East-import share) & $(4.01)$ & $(5.41)$ & $(3.28)$ & $(6.54)$ \\
& -0.033 & -0.038 & -0.024 & -0.087 \\
$\Delta \ln ($ ROW-import share) & $(2.39)$ & $(1.86)$ & $(1.33)$ & $(3.67)$ \\
& -0.049 & -0.170 & -0.040 & -0.125 \\
$\Delta \ln ($ East-export share) & $(1.11)$ & $(2.20)$ & $(0.71)$ & $(1.47)$ \\
& -0.008 & -0.002 & 0.015 & 0.010 \\
$\Delta \ln$ (ROW-export share) & $(0.76)$ & $(0.08)$ & $(1.18)$ & $(0.47)$ \\
$\Delta \ln ($ Output) & -0.021 & 0.028 & -0.030 & 0.012 \\
& $(0.58)$ & $(0.44)$ & $(0.60)$ & $(0.18)$ \\
Time trend & 0.313 & 0.402 & 0.381 & 0.373 \\
& $(6.95)$ & $(5.90)$ & $(7.13)$ & $(5.39)$ \\
$\mathrm{R}^{2}$ & 0.001 & 0.002 & -0.003 & 0.001 \\
$\mathrm{~F}$ & $(0.21)$ & $(1.44)$ & $(1.90)$ & $(0.96)$ \\
$\mathrm{N}$ & 0.324 & 0.373 & 0.297 & 0.466 \\
\hline
\end{tabular}

a All regressions include a constant. Absolute t-values in parentheses. Regressions weighted by employment share. Time period 1987-1994. $\Delta \ln$ (Foreign share) is instrumented. Instruments are lagged levels and changes in minimum wages, shares of blue-collar workers and EU output as well as lagged levels of immigrant shares. Low-wage industries refers to those with a mean wage level 87-94 up to the industry median; respectively for high-import and high-immigration. 
Table 7: Wage Growth: Austria ${ }^{a}$

\begin{tabular}{lcccc}
\hline & $\begin{array}{c}\text { All } \\
\text { industries }\end{array}$ & $\begin{array}{c}\text { Low-wage } \\
\text { industries }\end{array}$ & $\begin{array}{c}\text { High-import } \\
\text { industries }\end{array}$ & $\begin{array}{c}\text { High- } \\
\text { immigration } \\
\text { industries }\end{array}$ \\
\hline$\Delta \ln$ (Foreign share) & -0.164 & -0.112 & -0.099 & -0.081 \\
$\Delta \ln$ (East-import share) & $(2.58)$ & $(1.94)$ & $(0.82)$ & $(1.36)$ \\
& -0.021 & -0.009 & -0.005 & 0.027 \\
$\Delta \ln ($ ROW-import share) & $(0.78)$ & $(0.27)$ & $(0.14)$ & $(0.64)$ \\
& 0.098 & 0.099 & 0.139 & 0.062 \\
$\Delta \ln$ (East-export share) & $(1.15)$ & $(0.79)$ & $(1.19)$ & $(0.41)$ \\
& -0.021 & -0.012 & -0.045 & -0.047 \\
$\Delta \ln ($ ROW-export share) & $(0.99)$ & $(0.35)$ & $(1.73)$ & $(1.23)$ \\
& 0.240 & 0.189 & 0.311 & 0.348 \\
$\Delta \ln ($ Output) & $(3.34)$ & $(1.85)$ & $(3.26)$ & $(2.89)$ \\
Time trend & 0.307 & 0.227 & 0.250 & 0.178 \\
& $(3.50)$ & $(2.06)$ & $(2.27)$ & $(1.42)$ \\
$\mathrm{R}^{2}$ & -0.015 & -0.013 & -0.017 & -0.013 \\
$\mathrm{~F}$ & $(7.41)$ & $(5.38)$ & $(5.51)$ & $(5.38)$ \\
$\mathrm{N}$ & 0.316 & 0.259 & 0.328 & 0.267 \\
\hline
\end{tabular}

a All regressions include a constant. Absolute t-values in parentheses. Regressions weighted by employment share. Time period 1987-1994. $\Delta \ln$ (Foreign share) is instrumented. Instruments are lagged levels and changes in minimum wages, shares of blue-collar workers and EU output as well as lagged levels of immigrant shares. Low-wage industries are those with a mean wage level 87-94 up to the industry median; the same principle is applied for high-import and highimmigration industries. 
Table 8: Employment Growth: Germany ${ }^{\mathrm{a}}$

\begin{tabular}{lcccc}
\hline & $\begin{array}{c}\text { All } \\
\text { industries }\end{array}$ & $\begin{array}{c}\text { Low-wage } \\
\text { industries } \\
\text { only }\end{array}$ & $\begin{array}{c}\text { High-import } \\
\text { industries only }\end{array}$ & $\begin{array}{c}\text { High- } \\
\text { immigration } \\
\text { industries only }\end{array}$ \\
\hline Constant & 0.010 & 0.023 & 0.006 & 0.035 \\
$\Delta$ ln (Foreign share) & $(0.62)$ & $(1.18)$ & $(0.35)$ & $(1.20)$ \\
& 0.025 & -0.007 & 0.470 & -0.008 \\
$\Delta$ ln (Eastern Europe & $(1.16)$ & $(0.52)$ & $(2.84)$ & $(0.36)$ \\
foreigner share) & 0.966 & 1.763 & 0.377 & 1.014 \\
$\Delta \ln$ (Share of ethnic & $(2.82)$ & $(3.43)$ & $(1.12)$ & $(1.67)$ \\
Germans) & 0.018 & -0.051 & 0.045 & -0.049 \\
Russian share $\otimes \Delta \ln$ & $(0.62)$ & $(1.44)$ & $(1.29)$ & $(0.84)$ \\
(Share of ethnic Germans) & -0.047 & -0.121 & -0.147 & -0.020 \\
$\Delta \ln$ (Import share) & $(0.89)$ & $(2.11)$ & $(2.31)$ & $(0.22)$ \\
& 0.074 & 0.039 & 0.110 & 0.106 \\
$\Delta \ln$ (Export share) & $(2.99)$ & $(1.58)$ & $(1.89)$ & $(2.90)$ \\
$\Delta \ln$ (East import share) & -0.056 & -0.015 & -0.058 & -0.069 \\
& $(2.18)$ & $(0.67)$ & $(1.34)$ & $(1.78)$ \\
$\Delta \ln$ (East export share) & 0.050 & 0.153 & 0.008 & 0.140 \\
& $(0.94)$ & $(2.08)$ & $(0.14)$ & $(1.35)$ \\
$\Delta \ln$ (Output) & -0.043 & -0.115 & -0.015 & -0.102 \\
Time trend & $(1.06)$ & $(2.03)$ & $(0.36)$ & $(1.29)$ \\
$\mathrm{R}^{2}$ & 0.238 & 0.321 & 0.235 & 0.294 \\
$\mathrm{~F}$ & $(3.95)$ & $(2.78)$ & $(3.80)$ & $(2.30)$ \\
$\mathrm{N}$ & -0.006 & 0.001 & -0.005 & -0.008 \\
\hline & $(1.72)$ & $(0.30)$ & $(1.31)$ & $(1.56)$ \\
& 0.600 & 0.665 & 0.867 & 0.550 \\
& 14.56 & 8.52 & 28.02 & 5.25 \\
& 108 & 54 & 54 & 54 \\
\hline
\end{tabular}

a All regressions include a constant. Absolute t-values in parentheses. Regressions weighted by employment share. Time period 1986-1994. All foreigner shares are instrumented. Instruments are lagged levels and changes in union wages, shares of blue-collar workers and EU output as well as lagged levels of immigrant shares. Low-wage industries are those with a mean wage level 86-94 up to the industry median; the same principle is applied for high-import and highimmigration industries. 
Table 9: Native Employment Growth: Germany ${ }^{\mathrm{a}}$

\begin{tabular}{|c|c|c|c|c|}
\hline & $\begin{array}{c}\text { All } \\
\text { industries }\end{array}$ & $\begin{array}{l}\text { Low-wage } \\
\text { industries } \\
\text { only }\end{array}$ & $\begin{array}{l}\text { High-import } \\
\text { industries only }\end{array}$ & $\begin{array}{c}\text { High- } \\
\text { immigration } \\
\text { industries only }\end{array}$ \\
\hline \multirow[t]{2}{*}{ Constant } & 0.008 & 0.015 & 0.011 & 0.022 \\
\hline & $(0.49)$ & $(0.53)$ & $(0.62)$ & $(0.70)$ \\
\hline \multirow[t]{2}{*}{$\Delta \ln ($ Foreign share $)$} & -0.036 & -0.059 & 0.421 & -0.051 \\
\hline & $(1.53)$ & $(3.05)$ & $(2.50)$ & $(2.05)$ \\
\hline$\Delta \ln$ (Eastern Europe & 1.039 & 1.306 & 0.318 & 0.862 \\
\hline foreigner share) & $(2.77)$ & $(1.74)$ & $(0.93)$ & $(1.32)$ \\
\hline$\Delta \ln$ (Share of ethnic & 0.022 & -0.022 & 0.030 & -0.010 \\
\hline Germans) & $(0.69)$ & $(0.42)$ & $(0.85)$ & $(0.16)$ \\
\hline Russian share $\otimes \Delta \ln$ & -0.032 & -0.107 & -0.121 & -0.032 \\
\hline (Share of ethnic Germans) & $(0.56)$ & $(1.28)$ & $(1.86)$ & $(0.32)$ \\
\hline \multirow[t]{2}{*}{$\Delta \ln ($ Import share $)$} & 0.049 & 0.032 & 0.119 & 0.084 \\
\hline & $(1.82)$ & $(0.89)$ & $(2.01)$ & $(2.12)$ \\
\hline \multirow[t]{2}{*}{$\Delta \ln ($ Export share $)$} & -0.041 & -0.009 & -0.058 & -0.055 \\
\hline & $(1.45)$ & $(0.28)$ & $(1.32)$ & $(1.30)$ \\
\hline \multirow[t]{2}{*}{$\Delta \ln$ (East import share) } & 0.035 & 0.107 & 0.022 & 0.078 \\
\hline & $(0.61)$ & $(0.99)$ & $(0.39)$ & $(0.69)$ \\
\hline \multirow[t]{2}{*}{$\Delta \ln ($ East export share) } & -0.032 & -0.076 & -0.028 & -0.055 \\
\hline & $(0.71)$ & $(0.92)$ & $(0.64)$ & $(0.64)$ \\
\hline \multirow[t]{2}{*}{$\Delta \ln ($ Output $)$} & 0.250 & 0.394 & 0.243 & 0.366 \\
\hline & $(3.80)$ & $(2.33)$ & $(3.87)$ & (2.64) \\
\hline \multirow[t]{2}{*}{ Time trend } & -0.006 & 0.000 & -0.006 & -0.007 \\
\hline & $(1.78)$ & $(0.02)$ & $(1.57)$ & $(1.24)$ \\
\hline $\mathrm{R}^{2}$ & 0.574 & 0.484 & 0.867 & 0.558 \\
\hline $\mathrm{F}$ & 13.05 & 4.03 & 27.92 & 5.42 \\
\hline $\mathrm{N}$ & 108 & 54 & 54 & 54 \\
\hline
\end{tabular}

a All regressions include a constant. Absolute t-values in parentheses. Regressions weighted by employment share. Time period 1986-1994. All foreigner shares are instrumented. Instruments are lagged levels and changes in union wages, shares of blue-collar workers and EU output as well as lagged levels of immigrant shares. Low-wage industries are those with a mean wage level 86-94 up to the industry median; the same principle is applied for high-import and highimmigration industries. 
Table 10: Wage Growth: Germany ${ }^{\mathrm{a}}$

\begin{tabular}{lcccc}
\hline & $\begin{array}{c}\text { All } \\
\text { industries }\end{array}$ & $\begin{array}{c}\text { Low-wage } \\
\text { industries } \\
\text { only }\end{array}$ & $\begin{array}{c}\text { High-import } \\
\text { industries only }\end{array}$ & $\begin{array}{c}\text { High- } \\
\text { immigration } \\
\text { industries only }\end{array}$ \\
\hline Constant & 0.023 & 0.021 & 0.019 & 0.022 \\
$\Delta \ln$ (Foreign share) & $(2.39)$ & $(1.30)$ & $(1.29)$ & $(1.37)$ \\
$\Delta$ ln (Eastern Europe & 0.019 & 0.009 & -0.067 & 0.028 \\
foreigner share) & $(1.41)$ & $(0.81)$ & $(0.49)$ & $(2.18)$ \\
$\Delta \ln$ (Share of ethnic & 0.796 & 0.766 & 1.027 & 0.485 \\
Germans) & $(3.72)$ & $(1.87)$ & $(3.68)$ & $(1.44)$ \\
Russian share $\otimes \Delta$ ln & 0.013 & 0.028 & -0.030 & 0.031 \\
(Share of ethnic Germans) & $(0.70)$ & $(0.98)$ & $(1.03)$ & $(0.96)$ \\
$\Delta \ln$ (Import share) & 0.011 & -0.020 & 0.083 & -0.026 \\
& $(0.33)$ & $(0.45)$ & $(1.57)$ & $(0.51)$ \\
$\Delta \ln$ (Export share) & -0.019 & -0.022 & 0.033 & -0.039 \\
$\Delta \ln$ (East import share) & $(1.21)$ & $(1.14)$ & $(0.67)$ & $(1.93)$ \\
$\Delta \ln$ (East export share) & 0.003 & -0.014 & 0.040 & 0.011 \\
$\Delta \ln ($ Output) & $(0.17)$ & $(0.79)$ & $(1.10)$ & $(0.51)$ \\
Time trend & -0.001 & -0.008 & -0.019 & -0.011 \\
$\mathrm{R}^{2}$ & $(0.02)$ & $(0.14)$ & $(0.42)$ & $(0.19)$ \\
$\mathrm{F}$ & -0.008 & -0.001 & 0.009 & -0.005 \\
$\mathrm{~N}$ & $(0.33)$ & $(0.03)$ & $(0.27)$ & $(0.11)$ \\
\hline
\end{tabular}

a All regressions include a constant. Absolute t-values in parentheses. Regressions weighted by employment share. Time period 1986-1994. All foreigner shares are instrumented. Instruments are lagged levels and changes in union wages, shares of blue-collar workers and EU output as well as lagged levels of immigrant shares. Low-wage industries are those with a mean wage level 86-94 up to the industry median; the same principle is applied for high-import and highimmigration industries. 